\title{
Paracoccidioidomycosis: acute-subacute clinical form, juvenile type*
}

\author{
Silvio Alencar Marques ${ }^{1}$ \\ Rosangela Maria Pires de Camargo ${ }^{1}$
}

\author{
Joel Carlos Lastória ${ }^{1}$ \\ Mariangela Esther Alencar Marques ${ }^{1}$
}

DOI: http:/ / dx.doi.org/10.1590/abd1806-4841.20164953

\begin{abstract}
The authors report aspects of paracoccidioidomycosis, acute-subacute clinical form, juvenile type, in a 19-year-old female patient. Paracoccidioidomycosis, juvenile type, classically occurs in young patients, both sexes, with lymphoma-like aspects as initial presentation. However, following the natural history of the disease the lymph nodes assume patterns of infectious disease, as an abscess and fistulae. Systemic dissemination of the disease can occur and lethality and morbidity are significant in this clinical presentation.
\end{abstract}

Keywords: Inflammation; Lymph nodes; Paracoccidioidomycosis

Female patient, 19-year-old, from the countryside of the state of São Paulo, Brazil. She reported onset of cervical tumors 3 months before the consultation, with progressively increasing and worsening of symptoms accompanied by evening fever of up to $38^{\circ} \mathrm{C}$ in the last month. On examination, cervical and submandibular lymph nodes with increased volume were observed, at different developmental stages: from the absence of inflammation to clearly patterns of infectious disease, abscess consistency and fistulization, with ulcerated skin and purulent secretion (Figures 1 and 2).The diagnosis of acute/ subacute paracoccidioidomycosis, juvenile type, was confirmed by direct microscopic examination of lymph node secretion (obtained by aspiration), by histopathological examination, which revealed classical budding forms of Paracoccidioides spp., and by serology (double immunodiffusion technique), which showed a title of 1/32 (Figures 3 and 4). The patient was treated

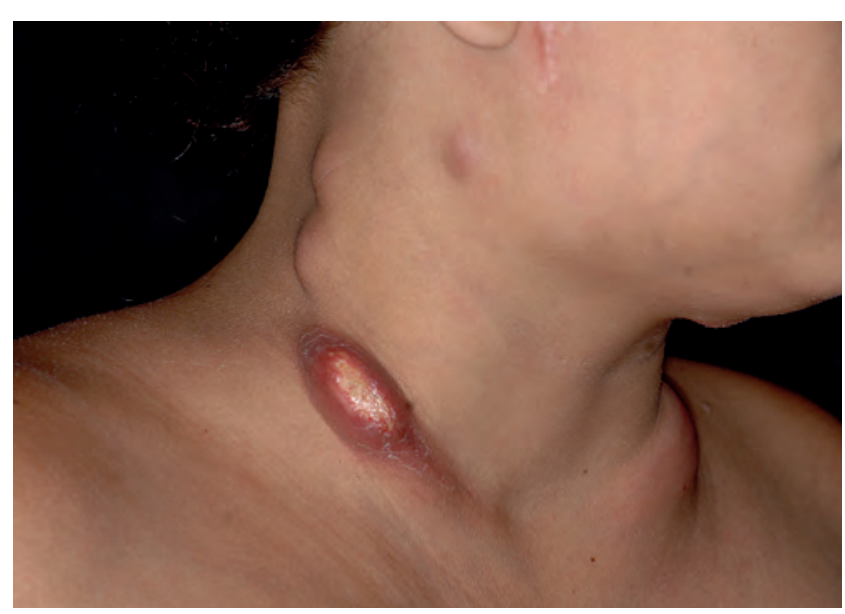

Figure 1 :Paracoccidioidomycosis: swollen lymph nodes with inflammatory aspect and fistula, ulcerated skin and purulent secretion (cervical and submandibular regions)

Approved by the Advisory Board and accepted for publication on 16.08.2015

Study performed at Departamento de Dermatologia e Radioterapia da Faculdade de Medicina de Botucatuof Unesp Financial Support: None.

Conflict of Interest: None. 


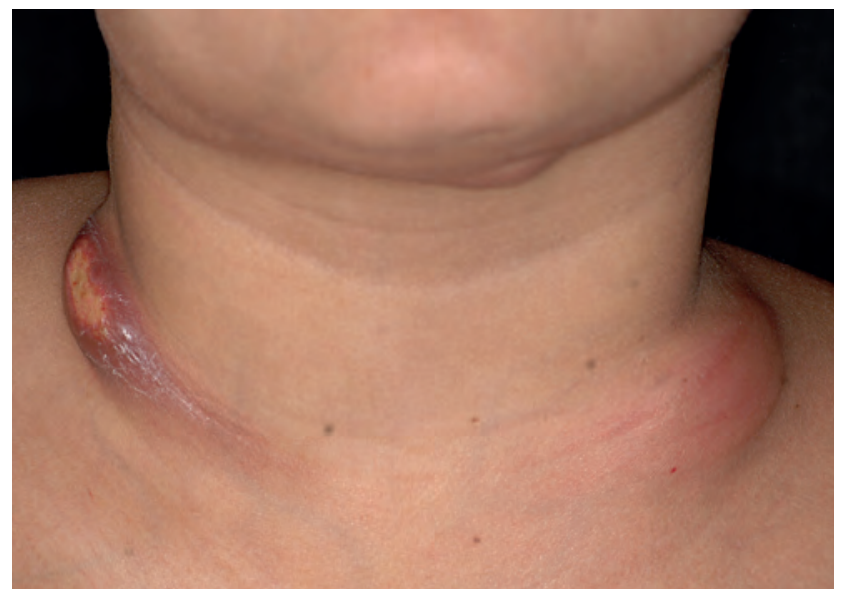

FIgURE 2 : Paracoccidioidomycosis: details of the lymph nodes with inflammatory aspect and fistulization

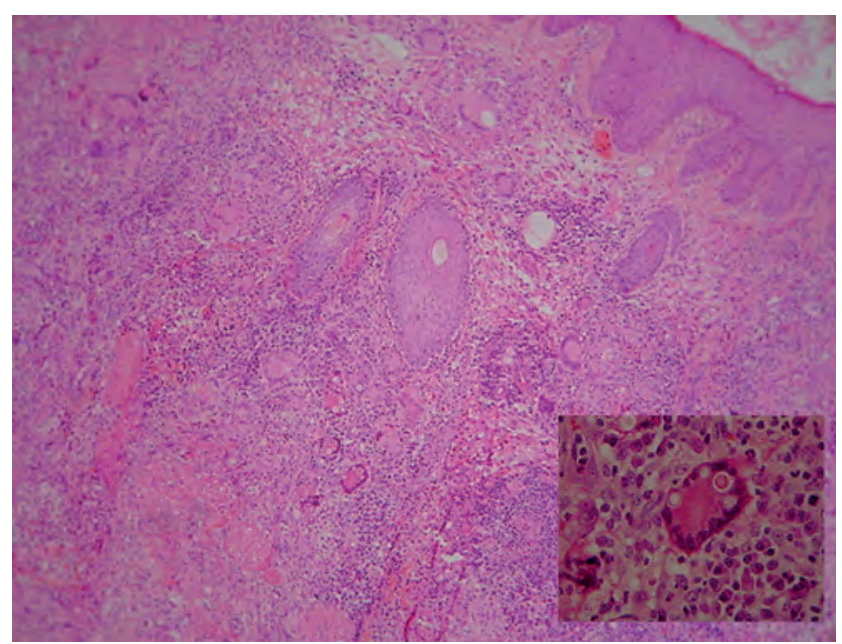

FIGURE 3 : Paracoccidioidomycosis: presence of hyperplasia of the epidermis and deep dermal inflammatory infiltrate with multiple giant cells harboring fungi (HE, 40x; detail: 200x)

with itraconazole $400 \mathrm{mg}$ /day for 2 months, reducing the medication to $200 \mathrm{mg} /$ day until treatment completed 12 months. There was clinical and serological remission.

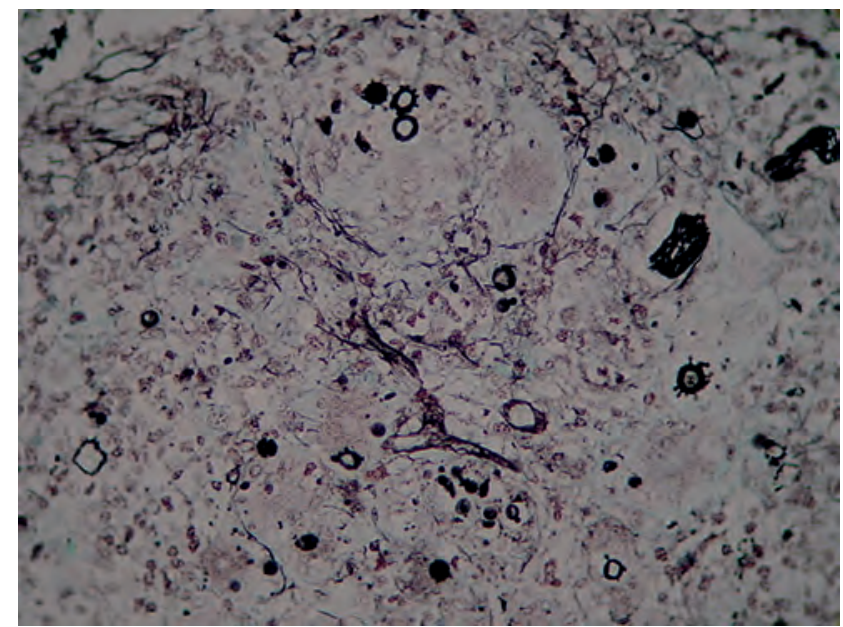

Figure 4 : Paracoccidioidomycosis: numerous multi budding yest cells in the dermis (Grocott-Gomori, 40x)

\section{DISCUSSION}

Acute/ subacute paracoccidioidomycosis, juvenile type, classically occurs in young patients of both sexes and is characterized by tropism of the fungus to the monocyte-phagocyte system. ${ }^{1-4}$

Clinically, it presents enlarged lymph nodes in superficial and deep chains, associated with liver, spleen and bone involvement. The initial framework resembles Hodgkin's lymphoma, with firm nodes, coalescing, associated with evening fever. ${ }^{5,6}$ In the evolution without treatment, lymph nodes assume inflammatory aspect, abscessing and fistulizing, as in this case. In this clinical form, the skin lesions are frequent and mucosal lesions are rare. The lymphatic and hematogenous dissemination makes it a serious condition with high mortality rate. ${ }^{7}$ 


\section{REFERENCES}

1. Marques SA. Paracoccidioidomycosis: epidemiological, clinical, diagnostic and treatment up-dating. An Bras Dermatol.2013;88:700-11.

2. Bellissimo-Rodrigues F,Bollela VR,Da Fonseca BA,Martinez R. Endemic paracoccidioidomycosis: relationship between clinical presentation and patients' demographic features. Med Mycol.2013;51:313-8.

3. Ballesteros A,Beltrán S,Patiño J,Bernal C,Orduz R. Disseminated juvenile paracoccidioidomycosis diagnosed in a girl from an urban area. Biomedica.2014;34:21-8.

4. Pereira GH,Santos AQ,Park M,Muller PR,Padua S,Marchesi RF,et al. Bone marrow involvement in a patient with paracoccidioidomycosis: a rare presentation of juvenile form. Mycopathologia.2010;170:259-61.

5. Barrozo LV ,Mendes RP, Marques SA, Benard G,Silva ME, Bagagli E. Climate and acute/subacute paracoccidioidomycosis in a hyper-endemic area in Brazil. Int $J$ Epidemiol.2009:38:1642-9

6. Resende LS, Mendes RP, Bacchi MM, Marques SA, Barraviera B, Souza $\mathrm{LR}$, et al. Infiltrative myelopathy by paracoccidioidomycosis. A review and report of nine cases with emphasis on bone marrow morphology. Histopathology.2006;48:377-86.

7. Marques SA, Cortez DB, Lastória JC, Camargo RMP, Marques MEA Paracoccidioidomicose: frequência, morfologia e patogênese de lesões tegumentares. An Bras Dermatol. 2007; 82:411-17.
MAILING ADDRESS:

Silvio Alencar Marques

Departamento de Dermatologia e Radioterapia

Faculdade de Medicina

Distrito de Rubião Junior, $\mathrm{S} / \mathrm{N}$

18618-970 - Botucatu - SP

Brazil

Email: smarques@fmb.unesp.br

How to cite this article: Marques SA, Lastória JC, Camargo RMP, Marques MEA. Paracoccidioidomycosis: acutesubacute clinical form, juvenile type. An Bras Dermatol. 2016;91(3):384-6. 